\title{
A New Approach to the Management of Mental Health Education for College Students
}

\author{
Xin $\mathrm{Su}^{1, \mathrm{a}^{*}}$ and Mao Yang ${ }^{2, \mathrm{~b}}$ \\ ${ }^{1}$ College of Science of Northeast Dianli University, Jilin, Jilin Province, China \\ ${ }^{2}$ Electrical Engineering College of Northeast Dianli University Jilin, Jilin Province, China \\ a814968539@qq.com, byangmao820@163.com
}

Keywords: Contemporary college students; Psychological health; Education; Countermeasures;

\begin{abstract}
With the development of the times, the traditional mode of education and management of college students is no longer meet the needs of contemporary college students. How to strengthen the ideological and political education of college students is a new task faced by the University educators. In this paper, through the analysis of the characteristics of contemporary college students and the lack of mental health education of contemporary college students, this paper expounds the new ways to further strengthen the education and management of College students. The innovation of the ideological and political education method needs to integrate the practice behavior into the educational activities, and cultivate the high quality development talents through social practice. Should not adapt to the development of education "restraint" education method into the teacher "guide" education method, for College Students Ideological and political education work effectively carried out and pointed out the correct direction.
\end{abstract}

\section{Introduction}

Every age has its own characteristics. With the distinctive characteristics of the times. In order to deal with this kind of change of university student's psychology. Major colleges and universities have successively carried out the mental health education activities, and established the university student psychological consultation organization. Many people think that the contemporary college students are smart, creative, but lack of social responsibility. This means that the psychological health education for the contemporary college students is facing severe challenges. Therefore, how to grasp the psychological characteristics of contemporary college students is of great significance.

\section{Ideological Characteristics of Contemporary College Students}

Most of them like the independent thinking of exhibition, in the process of practice fumble ceaselessly new ideas and methods, don't like cramming teaching mode. Nowadays, due to the rapid development of economy, the popularity of the network is getting higher and higher, and the degree of educational democracy has been greatly improved. The traditional mode of education and learning model has changed a lot[1]. The college students access to information and knowledge of the way more quickly. From some extent in terms of contemporary college students in the complexity of the knowledge structure and diversity beyond any previous era. They are eager to mature, independent, advocating freedom, don't like passively accept the transfer of knowledge and ideas, and hope to be able to with the teacher of equal exchange of the ditch and pass. In the communication process to improve the ability to analyze and solve problems, but at the same time they are too self centered, lack of teamwork and collective sense of honor, interpersonal skills are relatively weak.

Because of the Internet era, many college students indulged in network communication. Under the network environment, interpersonal communication mainly characters "images" audio and video as the carrier of direct communication. Network environment to benefit the communicative objects, college students can face just met pours her heart secret, bold speak his trouble, and don't have to worry about being laughed at others, most of the time can get communication channel of objects. 
This is good for college students to vent feelings, alleviate the pressure of the heart, promote mental health. However, the interpersonal communication in the network is virtual. Because of the lack of emotional contact and direct emotional experience, make false composition of the network information with more. If college students addicted to online dating for a long time, will greatly reduce the time to participate in collective activities and classmates, make real interpersonal tensions.thought more socialization of contemporary college students, their economic consciousness is stronger, than young people before the $80 \mathrm{~s}$, their mature earlier and develop faster[2]. They know the comprehensive relationships, from different way of looking at a variety of social change. Throughout the campus, many contemporary college students to participate in social practice, fry, speculative or entrepreneurship. Their goal orientation obviously affected by the environment of market economy, to present a more pragmatic tendency.

\section{The Problems Existing in the College Students' Mental Health Education}

Some colleges of education workers tend to mix up the psychological health education and moral education, the students all kinds of problems as ideological and moral problems[3]. Mental health education teachers in colleges and universities constitute, engaged in the work of ideological and political education teachers account for a large proportion. They commonly used the method of moral education to solve students' psychological problem, make mental health education has the tendency of moral education, ignoring the unique function of psychological health education, as a result, teachers earnestly to lectures and students' psychological problems still exist. And some onesided exaggerated the role of psychological health education, denied that exist in college students' political ideology, the outlook on life and values. These people believe that students a problem is psychological problem, as long as we work to strengthen the psychological counseling and psychological education, student's problem is solved. Now college students lack of psychological self-regulation ability, but the lack of scientific world outlook, outlook on life and values. To a person, faith is the soul of man, did not have the soul, people will lose the meaning of existence, human survival significance, to effectively regulate technology will become insignificant. Mental health education and moral education, there are both connection and difference between although both is to cultivate people's activities, but its task, contents, methods, means, value orientation is different. The purpose of mental health education is to cultivate students' good psychological quality and healthy personality, it makes every effort to make students know, self-confidence, selfdiscipline, and with high spirit of innovation and the ability to bear setbacks, to adapt to the environment, its core is the play to students' individual potential, prevent the happening of the psychological problems, and treatments for growth of psychological barriers[4]. Moral education is primarily a teaching process, it is a kind of ideology, moral norms impart to students, make students within the thought idea, the behavior standards into their own belief and action. Mental health education is a process of discussion and communication, the purpose is to the mind of communication to promote the self-examination and self-improvement of the parties, not to guide when help people grow up, use talks, psychological measurement, role play, more forms of life skills training, etc. Moral education have a clear value orientation, the key to success lies in seeking truth from facts; The psychological health education with value neutrality principle, is key to the success of the identity.Therefore, college students' psychological health education and moral education cannot replace each other, also cannot repel each other [5].

Because our country college psychological health education starts from the psychological consultation, solve the psychological barriers of students, the people lack of full understanding of the connotation of the psychological health education. Many colleges and universities will have been the focus of the mental health education is still on the psychological counseling and treatment of individual students, to solve the problem of college students' psychological, eliminate the psychological barrier or crisis intervention as the main starting point, suddenly rang its role in psychological health education, at the same time this model to the students the wrong impression. Some university students dare not timely advice when psychological puzzle, it can be eliminated by consulting psychological discomfort become obstacles, there are even more serious 
psychological crisis and took to the street. College students' mental health education should be aimed at arousing students' psychological potential, improve the students' psychological quality, develop the students' healthy personality, focus on the work of the psychological education of all students, at the same time for groups with mild mental disorder diagnosis and treatment, establish a prevention, the combination of prevention and treatment of mental health education model.

Our lack of a professional team of mental health education. From the point of current situation, personnel engaged in mental health education has the following categories: moral education workers, psychological workers, medical workers. In the mental health education personnel team are part-time workers. Such as the survey of 72 universities found that at present, the moral education teachers (55.4\%), psychology teachers accounted for $20.8 \%$, medical personnel account for $17.4 \%$, other $6.4 \%[6]$. A lot of people in the team didn't system study psychology knowledge, don't know the students' psychological law of development, not grasp psychological measurement technology, don't know basic principles and methods of psychological counseling skills. And psychological counseling is a science, is not a simple conversation, not what people can do, if misled as guide, counseling if processes is not good, can cause more damage to individuals and society. Even if a person psychology graduate counseling theories do not understand, or only know the theory but no practical experience, or do not have a certain degree of personal accomplishment and rich life philosophy of knowledge, do not fit in psychological counseling. Europe and the United States engaged in psychological health education personnel demanding, counseling workers, at least for a master's degree in counseling, and complete the required fields of the corresponding professional practice content and practice time. The actual operating time of a minimum of 300 hours, of which at least 200 hours of direct experience and 50 hours of service have formal internship supervisors[7].

By contrast, the degree of specialization of Mental Health Education team is not high. Specialization is a very pressing issue of Psychological Health Education of teachers need to be addressed.

\section{New Ways of Education Management of College Students}

Any youth of an era has its own characteristics, which results in the formation of these features are social, family, school and personal effects, and other factors. We can not criticize them too much to all the we could not understand the behavior or character[8]. We need to hold the usual attitude towards their prominent personality traits and characteristics appropriate for them to take advantage of these educational methods suited to their personality characteristics. First, we must recognize the existence of certain common personality traits in them, from their point of view and try to understand their behavior, so that empathy, the only way to better educational management.

To strengthen college students' mental health education of specification management must do the college students' mental health education into the university education work of the management system, strengthen the leadership, perfect the system[9]. Specific to the competent authorities responsible for students to work in the work, and set up the psychological health education of specialized agencies (commonly referred to as mental health or mental health education center education leading group), the agency responsible for specific implementation of mental health education, including planning, curriculum arrangement, the unity of psychological measurement requirements, and to examine the work instruction, etc. So, the agency must have sufficient funding and necessary office facilities, perfect rules and regulations, the advanced measurement software, stable teacher troop, perfect evaluation system and the forefront of scientific research. These institutional safeguard, the standardization of the management will be integral to promote college students' mental health education to a higher level of development.

Educators should strengthen the education of college students for security. The safety education should be included in the network environment of safety education and safety education in real life. For some of the network virtual characters and relationships, contemporary college students should have their own judgment standard, should not be easily poured out their privacy to strangers. Although on the social networking gives people a special kind of illicit close sex, but still can have 
privacy. Network is a double sword, as a modern college students should be enjoying the network provide us convenient also can clearly know that the network can bring inconvenience[10].

In short contemporary college students ideological and political education, to the scientific concept of development, people-oriented concept and technology and education, under the guidance of talent rejuvenating strategy, combined with the need of their own characteristics and the reality of society, the formation of correct and reasonable values, to promote their scientific development, comprehensive development. Ideological and political education should grasp the trend of the times, according to the new situation \# new characteristics, and constantly explore new educational laws and methods to promote the comprehensive development of students.

\section{References}

[1] Huang Zhibin. Contemporary ideological and political education methodology [M] Hefei: Hefei University Press, 2012: 133.

[2] Wen Xueping. Social psychology-based approach to talk about the effectiveness of ideological and political education [J] School Party Building and Ideological Education, 2006, (7): 15-16.

[3] Liu Xingeng. Modern ideological and political education methodology [M]. Beijing: People's Publishing House, 2006: 175-176.

[4] Fanhong Kui. College students ideological and political education innovation research [D]. Shandong Normal University, 2007: 4-6.

[5] Xie Zhifang. Interest network strengthening and improving ideological and political work [J]. Jiangsu Higher Education, 2002, (2): 103-104.

[6] $\mathrm{Xu}$ Mao. The evaluation mechanism of ideological and political education [J]. China Metallurgical Education, 2009, (3): 45-46.

[7] Wang Kaiyi. New period college students' Ideological and political education method innovation mechanism [J]. Modern marketing - academy version,2012,(4):298-299.

[8] Li Wenjing. A review of innovative research on ideological and political education of college students [J]. Science Journal,2012,(7):54-56.

[9] Hu Qing. Philosophical reflection on the reform of moral education in colleges and universities under the view of scientific development [D]. Soochow University,2007.

[10] You Chunyang. The innovation of ideological and political education of college students in the new era [J]. Intelligence,2012,(18):312-313. 